\title{
The Necessity of Cultivating "Application-Oriented, Compound-Oriented, Innovative and Entrepreneurial" Talents at the Undergraduate Level in Chifeng University*
}

\author{
Ya Zhang \\ Foreign Languages School \\ Chifeng University \\ Chifeng, China 024000
}

\begin{abstract}
Based on the development status of Chifeng University in the transition period, this paper proposes the necessity of cultivating undergraduate talents of "applicationoriented, compound-oriented, innovative and entrepreneurial" in Chifeng University. The aim is to explore the path of sustainable development of a local university, improve the quality of talent training in Foreign Languages School, and promote the economic development of Chifeng City and surrounding areas.
\end{abstract}

Keywords-Chifeng University; application-oriented; compound-oriented; innovative and entrepreneurial; undergraduate level talent

\section{INTRODUCTION}

Economic and social development requires both academic research talents and application talents that combine knowledge, skills and abilities. The crossdisciplinary integration and the enhancement of the integration trend are urgently needed for the comprehensive talents who can master the knowledge and skills of two or more disciplines. This urgently requires the adjustment of the structure of higher education and the development of classification. At the beginning of 2013, the Ministry of Education proposed to "guide a group of local undergraduate universities to transform into applied technology-based universities". The guidance for the pilot transformation and reform pilot in 2015 was issued. In 2016, Chifeng University was successfully approved as "the Inner Mongolia Autonomous Region Transformation Development Pilot University", and was also listed as one of the national "Applied Undergraduate Colleges and Universities for the Integration of Production and Education Development Projects". Therefore, the Foreign Languages School in Chifeng University adheres to the school philosophy of "integrating into Chifeng, serving the localities, highlighting characteristics, and transforming development", and

*This paper is the research result of Chifeng College's "Study and Implementation of the Key Project of the Third Party Congress of Chifeng University" (CYDDH201906). determines "taking undergraduate education as the main body, actively developing postgraduate education, moderately developing international cooperative education, and cooperating with higher vocational colleges to develop occupations. Education, and strive to expand continuing education." The Foreign Language School has carried out a series of reforms around it and tried some useful innovations. However, in order to smoothly realize the transformation and complete the "three-step" development strategy as scheduled, there are still many problems to be solved. The third party congress of the school put forward: "Proactively adapt to the new requirements of undergraduate education and further improve the personnel training system." It can be seen that improving the quality of undergraduate talent training has become the focus of Foreign Language School. According to the practical problems of the school's orientation and the current employment difficulties of college students, the author proposes the necessity of cultivating undergraduate talents of "application-oriented, compound-oriented, innovative and entrepreneurial" in Foreign Language School.

\section{ECONOMIC AND SOCIAL DEVELOPMENT NEED}

Higher education is the source of economic development, and economic development is inseparable from higher education. With the rapid development of the global economy, colleges and universities have become the center of social development and an important force guiding local economic development. Knowledge resources are the basic premise of sustainable economic development. The competition of talents has become the foundation of economic development among countries and regions. It has become the consensus of all countries in the world to vigorously develop education, cultivate various talents, and improve the quality of employment in accordance with the advantages of the country and region and economic characteristics.

With the rapid development of China's socialist market economy, the transformation and upgrading of the industry, the social and economic structure has shown a diversified 
development trend. The economic society has put forward new challenges to higher education. The demand for talents is more diversified and segmented, and higher requirements are placed on the overall quality, knowledge structure and skill level of the employed: understanding technology, operation, good management, performance management and acquiring a certain amount of multi-disciplinary knowledge. Due to the shortage of such talents, a large number of research results are at a theoretical level, but cannot be transformed into productivity in a timely manner, which seriously affects economic development and upgrading of industrial structure. Training talents, scientific research, and serving the society are the three major functions of higher education. The development of social economy requires that higher education must face the market and adapt to the development of the economy. In the process of economic transformation and upgrading, academic elites are required to provide theoretical guidance. Also, more applicationoriented talents in the front line who engage in practical operations, technology development and application, production management and capital operations are needed. At the same time, it needs some compound talents who have solid professional basic skills and master cross-major and interdisciplinary knowledge. With the acceleration of the entrepreneurial economic process, the public entrepreneurship and innovation have become the national development strategy. Cultivating innovative and entrepreneurial talents is an objective need for China's economic and social development.

Chifeng University is a local undergraduate college that was merged and promoted in 2003. It is mainly based on undergraduate education, taking into account the training of specialists and professional masters. Starting from the actual situation, the school has determined the overall goal of talent cultivation as: "With the guidance of Xi Jinping's new era of socialism with Chinese characteristics as the guide, with the virtue of the people as the fundamental task, cultivate and practice the core values of socialism, and cultivate the allround development of morality, intelligence, beauty and beauty. With the characteristics of social responsibility, innovation, practical ability and legal awareness, it has good professionalism, solid basic knowledge, and high comprehensive quality of ' application-oriented, compoundoriented, innovative and entrepreneurial talents' that meet the needs of regional economic and social development."

Therefore, Chifeng University's undergraduate level training of "application, compound, innovation and entrepreneurship" is a realistic need to adapt to China's economic and social development.

\section{THE NEEDS OF THE TRANSFORMATION AND}

\section{DEVELOPMENT OF LOCAL COLLEGES AND UNIVERSITIES}

In the 1990s, the state issued a number of "Opinions on Deepening the Reform of Higher Education System". Many colleges and universities in the whole country began to merge and reorganize. A new type of undergraduate colleges--new local undergraduate colleges came into being. They are formed by the combination of higher normal colleges, education colleges, TV universities, and middle schools in prefecture-level cities. Some are upgraded from higher vocational colleges to science, engineering, and engineering, and some are transformed from adult colleges. , distributed in more than 200 prefecture-level cities and above. At the beginning of these schools, blindly imitating key universities, the school is not well positioned, and the research-based and academic talent training model is followed, resulting in the cultivation of talents not reaching the elite level, lack of innovation and practical ability. With the adjustment of China's economic structure, the structure of talent demand has changed. Economic and social development requires a large number of "applicationoriented, compound-oriented, innovative and entrepreneurial 1" talents. This kind of talent training mode in local undergraduate colleges has seriously restricted the development of the local economy, and the situation of "difficult employment" and "labor shortage" has taken shape. The structure of higher education urgently needs adjustment and classification development. At the beginning of 2013, the Ministry of Education proposed to "guide a group of local undergraduate universities to transform into applied technology-based universities". In 2015, the state officially issued guidance on pilot reforms of transformation and development. In 2017, Premier Li Keqiang proposed in the government work report to continue to promote the transformation of some undergraduate institutions to the application.

The transformation of local undergraduate colleges into applied technology universities is China's development strategy, which is in line with the requirements of economic and social development transformation and upgrading. The "Modern Vocational Education System Construction Plan (2014-2020)" divides vocational education into three levels: primary, middle and high. Elementary and secondary vocational education cannot fully meet the current economic and social development needs of China, and vocational education at the undergraduate level has not yet been established. The transformation and development of local undergraduate colleges and universities, training high-level applied talents has further improved China's vocational education system and improved the training standards for talents. The cultivation of "application-oriented, compoundoriented, innovative and entrepreneurial" undergraduate talents at Chifeng University is the need for the transformation and development of local universities.

\section{Self-Sustainment And Sustainable DEVELOPMENT NEED}

At the end of the last century, the structure of higher education in China began to adjust, from the elite education stage to the popular education stage. The higher education system is constantly expanding, and the scale of new undergraduate colleges is also increasing, and the number of students enrolled has increased dramatically. As a new force in China's higher education, the newly-established local undergraduate colleges shoulder the heavy task of delivering qualified talents for local economic development. After nearly two decades of development, the newly established local undergraduate colleges have trained a large number of 
talents for local socio-economic development, and solved the problems that some comprehensive universities cannot meet the actual needs of local socio-economic development in terms of the number of talents and professional structure. It has played an important role in promoting the comprehensive development of a well-off society and serving the local economy. Although they have achieved great results in teaching, there are still some problems to be solved, especially compared with those established undergraduate colleges, which have a weaker development foundation and weaker core competitiveness. In today's fierce competition in higher education, it is still in a weak position. Advanced vocational colleges' advanced schoolrunning ideas, clear training goals, and especially the broad employment prospects have brought them great impact. In order to gain a place in the fierce competition in the talent market, newly-established local colleges and universities must be market-oriented, scientifically and reasonably positioned, give play to their own advantages, make strengths and avoid weaknesses, and take the path of running schools with unique characteristics. Explore a way of running a school different from traditional universities, a way of running a university that is unique during the period of popular education. Determine the "application, composite, innovative and entrepreneurial" talent training goals, and strive to cultivate talents with high comprehensive quality, solid theoretical foundation, broad professional knowledge, strong practical ability, excellent basic skills, close to society, and serve places. Only by this way can the grand goal be achieved continuously to fully build a well-off society and revitalize the local economy.

In the "Opinions on Vigorously Promoting Innovation and Entrepreneurship Education of Colleges and Universities and Independent Entrepreneurship Work of Colleges and Universities" issued by the Ministry of Education in 2010, it is stated that: "To enhance students' social responsibility, innovative spirit, entrepreneurial awareness and entrepreneurial ability as the core, vigorously promote higher education innovation Entrepreneurship Education. "The National Outline for Medium and Long-term Educational Reform and Development (2010-2020) states that "the structure of higher education shall be continuously optimized, the disciplines, majors, and hierarchies shall be optimized to promote cross-disciplinary and integration. Its focus is to expand the scale of application-oriented, composite, and skilled personnel training. "Chifeng University cultivates "application-oriented, compound-oriented, innovative and entrepreneurial" undergraduate-level talents in line with national strategic requirements and also the needs of its own survival and sustainable development.

\section{THE NEED FOR RELIEVING COLlEGE STUDENTS' EMPLOYMENT PRESSURE}

The era of the knowledge economy has put forward new requirements for the required talents, and future employees must have new knowledge, new horizons and new thinking. Since the expansion of colleges and universities at the end of the last century, China has had millions of college graduates every year. The employment problem of college students has become the most prominent problem in the whole society. Especially in recent years, the number of graduates has been hitting record highs. The number of college graduates in 2019 has reached 8.34 million, setting a new high in the number of graduates in the past 10 years, and the form of employment is very serious. The phenomenon of graduation and unemployment has increased year after year. However, some business people believe that suitable talents cannot be recruited and high-level application and compound talents are seriously lacking. Therefore, local undergraduate colleges and universities should meet the needs of the market and train the talents that society needs.

As early as 1998, China proposed that universities and colleges should cultivate innovative and entrepreneurial talents. The 18th National Congress of the Communist Party of China once again proposed "intensify the training of innovative and entrepreneurial talents, and guide talents to the frontline of scientific research and production." In 2013, President Xi also emphasized that "the whole society must attach importance to and support youth innovation and entrepreneurship, provide more favorable conditions, and build a broader stage so that the majority of young people can shine more brilliantly in innovation and entrepreneurship." (Xi Jinping congratulates the opening of China Station in Global Entrepreneurship Week 2013 - People's Daily, 2013-11-09). Therefore, contemporary college students must break away from the inherent "wait, rely, and demand" thinking mode, go out of the job market, start their own businesses, and realize their own value and spiritual pursuit. Chifeng University cultivates "applicationoriented, compound-oriented, innovative and entrepreneurial" undergraduate level talents to reduce the employment pressure of college students.

\section{CONCLUSION}

In short, Chifeng University will only meet the market demand by constructing an "applied, composite, innovative and entrepreneurial" undergraduate level talent training system, so that talent training can avoid the "education waste", "educational redundancy", "educational unemployment" and other social phenomena, and then successfully completed the transition to the application university.

\section{REFERENCES}

[1] Xue Yuxiang. Wang Zhanren. Research on the Cultivation Characteristics of Applied Talents in Local Universities [J]. Higher Engineering Education Research, 2016(1). (in Chinese)

[2] Chen Shiwei. Innovation and Entrepreneurial Talent Cultivation and Its Practical Significance [J]. Continuing Education Research, 2016(4). (in Chinese)

[3] $\mathrm{Xu}$ Yongli. Exploration of the "Five Forces" Model for the Cultivation of Innovative and Entrepreneurial Talents [J]. University Teaching in China, 2018(6). (in Chinese)

[4] Qi Li. Analysis on the Cultivation Path of Integrated and Innovative Entrepreneurial Talents [J]. Journal of Harbin Vocational and Technical College, 2017(5). (in Chinese) 